\title{
TOURIST MOBILE APPLICATIONS: EVALUATION OF THE VISITMALOPOLSKA APP
}

\author{
Iryna Manczak ${ }^{\mathrm{a}}$ (D), Maria Bajak ${ }^{\mathrm{b}}$ \\ ${ }^{a}$ Cracow University of Economics, College of Management and Quality Sciences, Faculty of Management, Departament \\ of Commerce and Market Institutions; https:/orcid.org/0000-0002-9661-9945; e-mail: manczaki@uek.krakow.pl \\ ${ }^{\mathrm{b}}$ Cracow University of Economics, College of Management and Quality Sciences, Faculty of Management, Departament \\ of Marketing; https://orcid.org/0000-0003-4769-7696; e-mail: bajakm@uek.krakow.pl
}

\begin{abstract}
The aim of the article is to evaluate the functionality of the VisitMalopolska mobile application developed for tourists. An attempt is made to outline ideas that allow tourists to explore Małopolska on their own, as well as to facilitate access to information about the region. The study focuses on the diverse use of mobile applications in tourism and in addition discusses the objectives and research method used. The main part of the discussion concerns the characteristics and evaluation of the most important functionalities of the new VisitMalopolska tourist application. In the main part of the article the most important functionalities available are evaluated and to do this, the point method was used
\end{abstract}

\section{KEYWORDS}

mobile technologies, mobile applications in tourism, Małopolska, VisitMalopolska

\section{ARTICLE INFORMATION DETAILS}

Received:

20 October 2020

Accepted:

13 April 2021

Published:

11 June 2021

\section{INTRODUCTION}

Modern mobile technologies enable the creation of useful ideas in many sectors of the economy and products are being developed as a result of these technologies. It is worth noting that in recent times there has been a significant increase in the number of mobile device users in Poland. At the end of 2018, it was found for the first time that the number of Polish internet users using smartphones or tablets was greater than that for desktop computers (Dąbrowski, 2019) and this data inspires those who are interested in implementing projects that involve the provision of mobile tools which allow basic tasks in the area of market communication to be achieved (Sznajder, 2014). It should be added that mobile technologies have influenced the emergence of communication platforms that enable the provision of services through multi-channel media without losing their integrity and the quality of their content (Kachniewska, 2019).
Mobile technologies are an inseparable part of everyday life both from the perspective of individual users as well as various formal bodies (Martin, Ertz berger, 2013; Parys, 2016). An example is provided by mobile applications which should be considered as a follow-up to the implementation of information and communication techniques in business practice (Czajkowski, Nowakowski, 2015), and are one of the basic tools for mobile marketing (Zawadzki, 2018). These applications have mainly social, entertainment, educational and informational functions (Kubiak, 2015) but for a long time mobile applications have been used in tourism as well (Da Silva, Da Rocha, 2012; Liang, Schuckert, Law, Masiero, 2016; Pawłowska-Legwand, 2019). The general trend shows that travel in the era of information and communication technologies has changed its character and is now offered a rich set of conveniences, including mobile applications (Niemczyk, 2017; Tan, Lee, Lin, Ooi, 2017; Gadziński, 2018; Dorcic, Komsic, Markovic, 2019). Tourists have 
more opportunities to organize travel without the help of travel agencies (Papińska-Kasperek, 2013) and for this purpose mobile applications are used.

Mobile applications are used in handling tourism on national as well as international levels (Lee, Choi, 2016). Most often they are an important element of the tourist information system (Zawadzki, 2018), as well as a useful tool for urban tourism (Papińska-Kacperek, 2016). This type of software allows tourists to plan their own sightseeing routes, including the quick finding of desired points of interest in an immediate vicinity (Piechota, 2014). A translation function is a popular mobile application making it possible to complete formalities during a journey (Rasińska, Siwiński, 2015) while tourists also have at their disposal, for example, applications made available by museums that make it easier for users to familiarize themselves with their resources and activities (De Rosset, Zielonka, 2016; Gmiterek, 2017).

The article attempts to evaluate the key functionalities offered by the VisitMalopolska mobile application. This is an element of the m_MISIT project, the mobile Małopolska Tourist Information System, initiated by the local government of the Małopolska Region in 20142020. The evaluation of its functionalities was based on a point method and it highlights selected issues regarding the use of mobile applications in tourism.

\section{MOBILE APPLICATIONS IN TOURISM}

Mobile applications are being implemented successfully in tourism and the industry will have a significant impact on further development of these technologies (Kim, Kim, 2017). The use of mobile applications in tourism is not a new phenomenon (Brown, Chalmers, 2003; Buhalis, Law, 2008), on the contrary, there are numerous examples of their implementation in tourist activities (Nunes, Mayer, 2014; Law, Cheng Chu Chan, Wang, 2018). However, it is still justified to initiate projects that assume a wider use of mobile applications in business practice. These activities should be treated as initiatives of a forward-looking nature, including those valuable from the point of view of the expectations of various stakeholder groups (including tourists, tourism industry bodies, and local government). It is worth mentioning that mobile applications are tools that after their implementation usually require little financial input, apart from the costs of maintenance and further development (Zawadzki, 2018). Such a feature may be of particular importance, and it may imply a number of benefits from the point of view of those implementing projects based on the applications.

Mobile applications are software designed for mobile phones. They are either paid for or free and in the vast majority of cases available from online application stores (Zawadzki, 2018). Mobile applications can be divided into (Hamza, Hammad, 2020; Sharma, Kumar, 2020):

- native apps - prepared for specific mobile devices and their operating systems. They are developed in a particular programming language and linked to a specific mobile platform (e.g. Android, iOS),

- responsive web apps - a special version of a website which is additionally adapted to be operated by mobile devices,

- hybrid apps - software compatible with different mobile platforms that can use the functionalities of a phone (e.g. camera, GPS, calendar, etc). They combine the advantages of native and web apps and are currently the most popular type of software.

Assuming the purpose of a mobile application as the criterion, the following, for example, can be distinguished: information applications, educational software, social programs, business and office applications, financial and banking programs, shopping applications, navigation and location programs, tourist applications, health and sports programs, games and entertainment software, music and film programs. Based on the above classification, it should be recognized that mobile applications can have different functions and uses while in practice, most of the available applications combine functionalities from many of these areas.

Implementing innovative concepts at tourist destinations can contribute, thanks to an active tourism policy of a particular region, to a significant increase in the level of attractiveness, including having an impact on the competitiveness of the areas in question and thus influence the number of tourists (Panasiuk, 2015). The diversity of a regional tourist offer requires not only cooperation based on coherence, but also distinguishing the region from other competitive tourist destinations (Manczak, 2014). This goal can be realized within the framework of projects dedicated to developing and making mobile applications available. It should be added that tourist mobile products are often created on behalf of public bodies that recognize the need to prepare websites and programs for mobile devices, as well as to provide free multimedia resources (PapińskaKacperek, 2016).

Research conducted by Pawłowska-Legwand (2019) shows that tourists are keen to use information and communication technologies before departure and are most interested in digital tools that provide access to the variety of information needed to help organize a trip. Above all, this information concerns planning, movement and selected tourist attractions. The most popular mobile applications are communication programs: searching for parking spaces or public transport connections, allowing taxis to be ordered as well as providing mobile guides (Papińska-Kacperek, 2016). 
The implementation of applications allows greater interaction with tourists, and thus helps to better adapt the product to their expectations (Piechota, 2014). It is worth noting that the behavior of a consumer who uses this kind of technology comes with a certain dissonance. On the one hand, they use tools already known, based on previous habits, on the other, they are looking for new, more technologically advanced possibilities in order to optimize the process of planning their experiences as tourists (Xiang, Magnini, Fesenmaier, 2015). The deeper tourists immerse themselves in a given technology, the more intensively they feel the experience connected with it. Neuhofer, Buhalis and Ladkin (2014) distinguished several levels in the perception of technological support by tourists:

- conventional experience,

- experience aided by technology,

- experience enriched by technology,

- experience stimulated by technology.

These perspectives are connected with the concept of a 'smart tourist', who uses various available digital tools both before and during a trip, including applications, sensors, Wi-Fi, big data and more (Gretzel, Sigala, Xiang, Koo, 2015). At the same time, combining conventional and technological experiences is a factor that for smart tourists increases the attractiveness of destinations (Buonincontri, Micera, 2016; Brennan, 2020). It should be noted that according to the data presented in the Turyści 2019 report, almost half the tourists in Poland with Android smartphones use mobile applications for tourism and on the basis of measurements from previous years, there is a noticeable upward trend (Spicy Mobile, 2019). In the light of the comments, it may be assumed that such software is one of the fundamental elements of smart tourism.

Taking into account the possibilities of mobile applications, including the preferences of their users, it should be stated that such tools are gaining support among tourists. It is worth noting however that this can take different forms. In domestic tourism, there are a variety of tools dedicated to particular audiences which include:

- maps and navigation systems (Traseo, Szlaki Trasy Mapy);

- applications for planning transportation routes (Koleo e-podróżnik.pl, BlaBlaCar);

- accommodation booking software (Meteor24, Niedrogie hotele, booking.com, Airbnb);

- guides to sites of cultural heritage (Wilanów Guide, Muzeum Książąt Czartoryskich, Muzeum Śląskie);

- programs supporting sports tourism (KajakTour, Szlaki Tatry, Green Velo);

- applications dedicated to participants of cultural events (Pol'And'Rock, Jewish Culture Festival, Rzeszowski Festiwal Jazzowy);
- urban guides (Bydgoszcz - Mobilny Przewodnik; Gdańsk, Gdynia, Sopot, Hel - Przewodnik po Trójmieście; Mobilny Przemyśl Częstochowa - przewodnik);

- regional guides (VisitMalopolska, Konstelacje dobrych miejsc - Paszport Turystyczny, Karkonosze, Bieszczady \& Górny San).

The popularity of mobile applications and the variety of software available on the Polish market, as well as the constant emergence of new ones, may be influenced by new phenomena in the contemporary tourism market. It is worth noting that increasingly often, tourists are looking for personalized offers, including those taking into account their individual expectations and preferences (Manchak, Sanak-Kosmowska, 2018). Therefore, it is important to emphasize the need to create increasingly dynamic, flexible and intelligent open tools, capable of responding to the needs of the tourist in real time (Perez Pulido, 2016). Realization of these expectations may promote tourist mobile applications.

\section{THE AIM OF THE RESEARCH AND THE RESEARCH METHOD}

The key objective of the article is to evaluate the functionalities available on the VisitMalopolska tourist application. Taking into account this research goal, it was decided to identify tools enabling independent sightseeing, as well as facilitating access to tourist information about the Małopolska region.

For the purpose of this research, the following specific questions were formulated:

- what are the most important tasks of the analyzed applications?

- who is the target audience of the application?

- what new technologies does the application use?

- how does the application contribute to the promotion of Małopolska?

- how does the application contribute to the development of tourism in the region?

This article attempts to identify the opportunities offered by the selected mobile application and was achieved on the basis of a literature analysis and an analysis of the materials available concerning the software. It was decided to make a point evaluation of the functionality available in the application from the point of view of different target groups. In the literature it is accepted that this method allows the evaluation of anything according to a set of criteria (SzyranResiak, 2016; Gierszewska, Romanowska, 2017). The aim of the method is to create a list of criteria (factors) that will allow what is analyzed to be described and differentiated (Thompson, Strickland, 1997). These are 
assigned appropriate weightings (because not all of them have the same value) to which points (scores) are awarded from a selected numerical range (SzyranResiak, 2016). One of the principles adopted for weighting evaluation criteria is their selection using the help of 'expert reviews' (Ziernicka-Wojtaszek, Zawora, 2011). Individual experts' opinions also apply to the determination of subjective probability, including verifying the ratings. According to Stabryła (2013) such judgments are the result of opinions issued on the basis of certain preferential premises. It was decided to use this approach and an attempt was made to identify the key functionalities of the mobile application. The authors decided to use their own experience while using the selected mobile software.

For the purposes of the research, it was decided to make a slight modification to the point method. The individual functionalities have been evaluated from the point of view of usability for different tourist target groups. Above all, it was recognized that the needs of each user are equally important and therefore different weightings were not given. A scale of 1 to 5 was used, assuming that:

- 5 implies a very useful functionality,

- 4 implies a useful functionality,

- 3 implies a functionality that can be useful,

- 2 implies a barely useful functionality,

- 1 implies a functionality without value.

The scores for each functionality are then summed and the average was calculated for each category. The functionalities of the VisitMalopolska application were divided into several categories according to their purpose and evaluated. An attempt was also made to discover the most important tasks achieved by the VisitMalopolska application.

\section{VISITMALOPOLSKA APPLICATION - PROJECT ASSUMPTIONS}

The VisitMalopolska application is an element of the m_MSIT project a mobile Małopolska Tourist Information System, implemented in 2014-2020 by the local government of the Małopolska Region ${ }^{1}$. Its primary goal is to create a digital platform that will enable the presentation of the regional tourist offer using modern technologies and multimedia tools and make it available to both tourists and residents of the region. The m_MSIT project provides for facilitating access to information in the field of tourism, as well as supporting independent sightseeing in Małopolska (VisitMalopolska, 2020a). Its implementation has been divided into several stages (Table 1).

The VisitMalopolska application uses its own functionalities as well as the capabilities of the device on which it is installed. Due to its use, the tool can be regarded as a source of cultural and tourist information about the region, including navigation and location. This software is addressed both to residents of the Małopolska region, and to domestic and foreign tourists, therefore the mobile software is available in eight languages (Polish, English, German, Spanish, French, Italian, Slovak and Russian). Moreover, the integration of tourists and residents is supported by a functionality that enables translation of basic phrases between those languages.

The software allows users to direct the content to those sightseeing on foot, by bicycle or car. The user can choose the type of tour from among the following topics: 'Mountains', 'For children', 'Trail of the First War' [World War I trail], 'Actively in the Summer' [Summer/ Winter activities (depending on the season)], 'Sacrum' [religious sites] or 'Tourist Routes'. Following the choice of topic, the available content is filtered according to the indicated preferences and divided into the following categories: news, points of interest (POIs), events and tourist routes. The user can view this content displayed in the form of a list, sorted chronologically (news and events) or alphabetically (tourist places and routes) as well as POIs marked on the map (Fig. 1).

In accordance with the assumptions of the project, an important part of the application is cooperation with multimedia tools to present the tourist offer of the region (VisitMalopolska, 2020a). The basic approaches in the area of new technologies applied within the VisitMalopolska program are:

- beacons - sensors using bluetooth technology to communicate with a device equipped with compatible software (Manczak, Sanak-Kosmowska, Bajak, 2019),

Table 1. Stages of implementation of m_MSIT

\begin{tabular}{|c|l|}
\hline Specification & \multicolumn{1}{|c|}{ Key tasks } \\
\hline $1^{\text {st }}$ stage & $\begin{array}{l}\text { expansion of the system for sharing and presenting resources related to tourism and regional heritage by creating } \\
\text { a web portal and mobile application with a travel planner, as well as purchasing and programming beacons con- } \\
\text { necting to this software }\end{array}$ \\
\hline $2^{\text {nd }}$ stage & collecting and sharing tourist information (especially related to bicycle tourism) through the m_MSIT digital system \\
\hline $3^{\text {rd }}$ stage & $\begin{array}{l}\text { expansion of the software through the use of } 360^{\circ} \text { films (in 2D and 3D technology) made at selected tourist } \\
\text { attractions from the Małopolska region }\end{array}$ \\
\hline
\end{tabular}

Source: VisitMalopolska (2020a). 


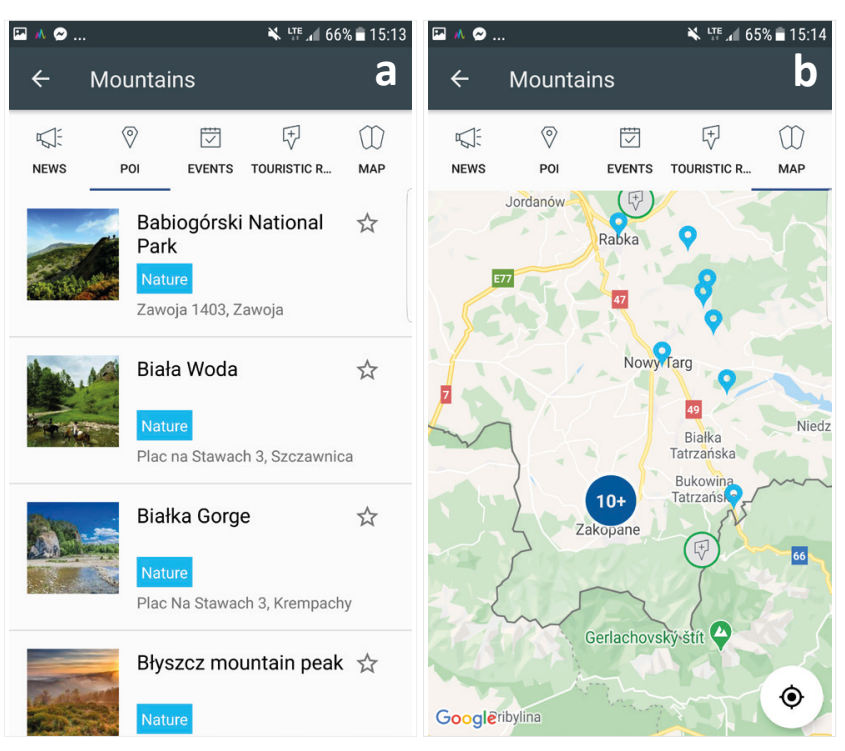

Figure 1. A screen print from the VisitMalopolska application showing a list of attractions related to the theme of mountains in the Małopolska region as a list (a) and on a map (b)

Source: own research

- augmented reality - a visual system which applies information and images from a computer environment (Peddie, 2017),

- artificial intelligence - a set of different technologies that combine data, computing power and algorithms by acquiring, processing and interpreting them to achieve a goal.

Beacons enable the transmission of information, the microlocation of people and places, and the collection of data about their users (Manczak, Sanak-Kosmowska,
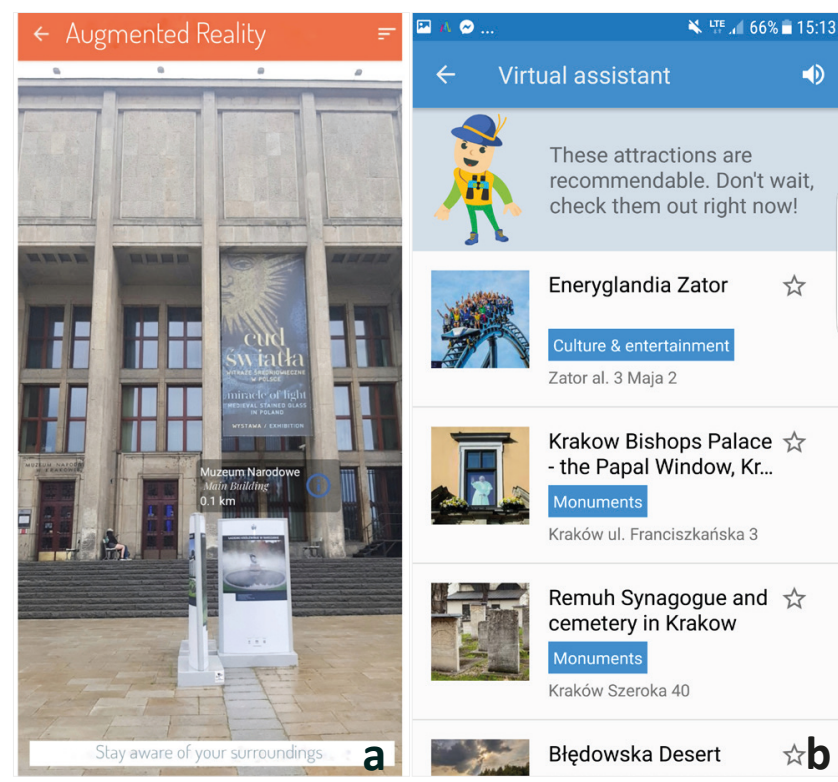

Figure 2. A screen print from the VisitMalopolska application showing functions related to augmented reality (a) and artificial intelligence (b)

Source: own research
Bajak, 2019). It is worth noting that in 2016-2019, as part of the m_MSIT project, 1,000 beacons were installed in 83 locations in the Małopolska region. Once within range, the user receives the relevant content related to the place visited (VisitMalopolska, 2020b). The VisitMalopolska application also uses augmented reality allowing the user to connect reality with the virtual world through simulations, projects, illustrations and content (Peddie, 2017). As a result, it is possible to gain automatic access to content related to the selected tourist attraction after placing it in the camera lens of a mobile device (Fig. 2a).

Artificial intelligence systems can adapt their behavior by analyzing their previous approaches and can learn using a numerical model (European Commission). The VisitMalopolska software allows users' behavior (e.g. places viewed, events, routes or planned trips) to be observed and analyzed in order to suggest tourist attractions that they are more likely to actually enjoy (Fig. 2b).

\section{EVALUATION OF THE FUNCTIONALITIES OF THE VISITMALOPOLSKA MOBILE APPLICATION}

The quality of mobile applications is analysed using various criteria and one of them is their functionality. Functionality is defined as the availability of certain features within the selected mobile application and can be measured from the functional requirements specified for the research undertaken (Zborowski, Łuczak, 2016).

The main goal in creating the VisitMalopolska mobile application is to enable independent sightseeing, as well as to facilitate access to tourist information about the region (VisitMalopolska, 2020b). The implementation of this intention possible thanks to the application functionalities and carefully selected thematically-divided content (Fig. 3). To work properly, the application requires Bluetooth on the phone and by activating its GPS location. In addition, the augmented reality function in the software uses access to the device's camera. As a result, the user gets full access to all functionalities within the application (Table 2).

The functionalities of the VisitMalopolska application can be divided into four categories according to their purpose:

- category I (tourist attractions) - 'news', 'events', 'places', 'thematic modules', 'bicycle touring';

- category II (tools supporting trip planning) - 'map', 'travel planner', 'tourist routes', 'favorites';

- category III (tools used during a tourist trip) -'phrasebook', 'postcard', 'outdoor games', 'augmented reality', 'virtual assistant';

- category IV (application and user safety tools) - 'emergency numbers'; 
Table 2. Overview of VisitMalopolska app functionalities

\begin{tabular}{|l|l|}
\hline \multicolumn{1}{|c|}{ Feature } & \multicolumn{1}{c|}{ Specification } \\
\hline News & Notifications about events, programs and initiatives implemented in the Małopolska region \\
\hline Events & Information on regional cultural, scientific and sporting events \\
\hline POIs & Specification and description of regional tourist attractions \\
\hline Favorites page & A list of content of particular interest to the user \\
\hline Map & Map of the region with marked tourist attractions \\
\hline Travel planner & A tool to help the user arrange their own tour plan \\
\hline Thematic modules & In-app content grouped by selected topics \\
\hline Tourist routes & Suggestions for tours of the region \\
\hline Bicycle touring & Cycling content \\
\hline Phrasebook & Dictionary of phrases useful for travel in eight languages \\
\hline Postcard & Virtual postcard wizard \\
\hline Field games & Routes where points and prizes are awarded \\
\hline Augmented reality & Overlay with information about tourist attractions visible in the camera on the user's phone \\
\hline Emergency telephone numbers & List of emergency numbers \\
\hline Virtual Assistant & Tourist attraction suggestions based on user behavior within the app \\
\hline Settings & Tool to manually customize the application to individual needs \\
\hline
\end{tabular}

Source: own research.

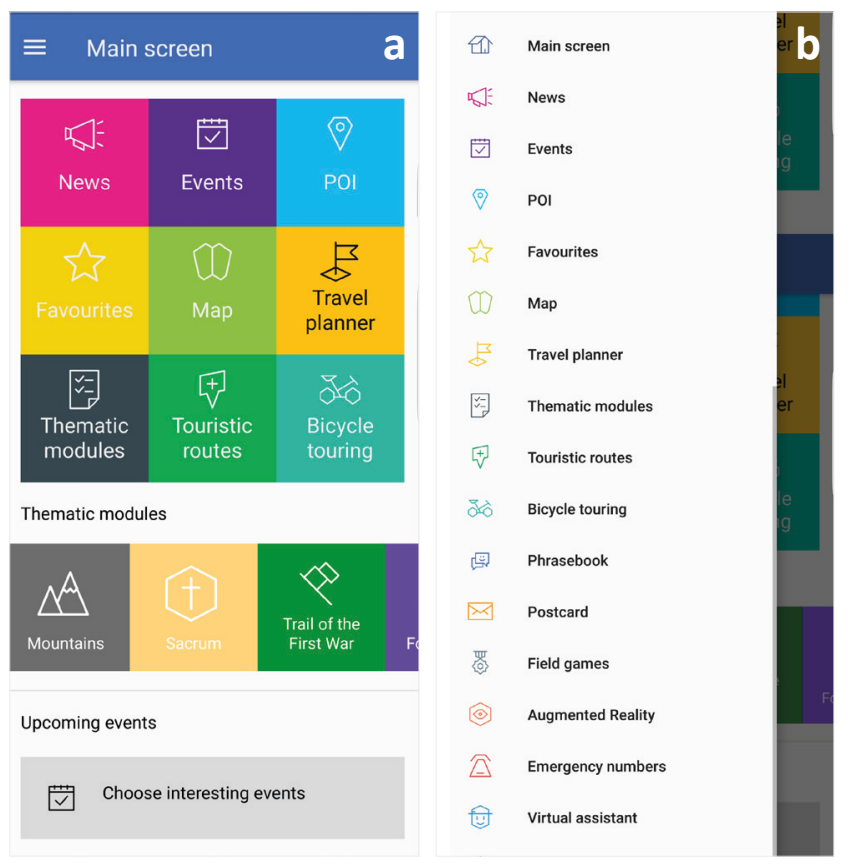

Figure 3. A screen print of the home page (a) and side menu (b) on the VisitMalopolska application Source: own research

All the functionalities of the application are focused on providing information support for tourist trips in the Małopolska region. Their wide range makes the mobile software useful for different types of tourists, including those who prefer both passive and active tourism.

Characteristic target groups can be distinguished and categorized based on the types of tourists proposed by Przecławski (1979):
- the cognitive tourist - oriented towards learning about culture, nature and/or people;

- the integrative tourist - focused on group experiences;

- a task-oriented tourist - willing to take specific action;

- a high-performance tourist - oriented towards physical activity and adventure;

- a tourist for entertainment - seeker of entertainment and passive recreation;

- a contemplative tourist - interested in religious sites, pilgrims;

- the health tourist - focused on caring for health.

In order to assess the usability of particular functionalities for different target groups, the point method was used (Table 3 ) but it was decided not to include the category of tools concerning application performance and user safety. On the basis of the evaluation, it was assumed that for users, functionalities from the category of tools supporting travel planning may be the most important (30.5 points). Other important functionalities include the thematic distribution of content (35 points), favorites (34 points), tourist routes (31 points), maps (29 points) and POIs (29 points). In addition, features such as the travel planner (28 points), events ( 27 points), virtual assistant ( 26 points) and field games ( 25 points) may be useful for most target groups. It can be noted that the cognitive tourist is perhaps the main target audience of the application (66 points), and tourists for entertainment (61 points) and taskoriented tourists (56 points) should also be considered as particularly important categories of user.

Point evaluation was combined with user reviews of the software available at Google Play and the App Store. 
Table 3. Target audiences of the VisitMalopolska app

\begin{tabular}{|c|c|c|c|c|c|c|c|c|}
\hline \multirow[b]{2}{*}{ Feature } & \multicolumn{7}{|c|}{ Tourism } & \multirow[b]{2}{*}{ Total } \\
\hline & 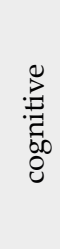 & 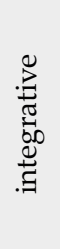 & 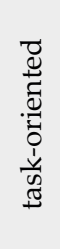 & 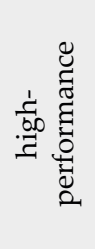 & 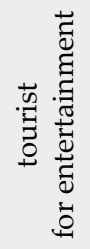 & $\begin{array}{l}\frac{0}{\pi} \\
\frac{\pi}{2} \\
\frac{0}{0} \\
\stackrel{0}{0} \\
0\end{array}$ & 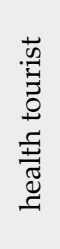 & \\
\hline \multicolumn{9}{|c|}{ Category I - tourist attractions } \\
\hline News & 4 & 4 & 3 & 2 & 5 & 3 & 3 & 24 \\
\hline Events & 5 & 5 & 3 & 2 & 5 & 4 & 3 & 27 \\
\hline POIs & 5 & 2 & 3 & 5 & 4 & 5 & 5 & 29 \\
\hline Thematic modules & 5 & 5 & 5 & 5 & 5 & 5 & 5 & 35 \\
\hline Bicycle touring & 5 & 3 & 5 & 5 & 2 & 1 & 1 & 22 \\
\hline \multicolumn{8}{|l|}{ Average number of points in category I } & 27.4 \\
\hline \multicolumn{9}{|c|}{ Category II - tools to support travel planning } \\
\hline Map & 5 & 2 & 5 & 5 & 2 & 5 & 5 & 29 \\
\hline Travel planner & 5 & 3 & 5 & 5 & 4 & 3 & 3 & 28 \\
\hline Tourist routes & 5 & 2 & 5 & 5 & 4 & 5 & 5 & 31 \\
\hline Favorites & 5 & 4 & 5 & 5 & 5 & 5 & 5 & 34 \\
\hline \multicolumn{8}{|l|}{ Average number of points in category II } & 30.5 \\
\hline \multicolumn{9}{|c|}{ Category III - tools used during a trip } \\
\hline Phrasebook & 5 & 5 & 3 & 1 & 5 & 1 & 1 & 21 \\
\hline Postcard & 2 & 5 & 1 & 1 & 5 & 1 & 1 & 16 \\
\hline Field games & 5 & 5 & 5 & 3 & 5 & 1 & 1 & 25 \\
\hline Augmented Reality & 5 & 1 & 3 & 2 & 5 & 1 & 1 & 18 \\
\hline Virtual Assistant & 5 & 3 & 5 & 4 & 5 & 2 & 2 & 26 \\
\hline \multicolumn{8}{|l|}{ Average number of points in category III } & 21.2 \\
\hline TOTAL & 66 & 49 & 56 & 50 & 61 & 42 & 41 & 365 \\
\hline
\end{tabular}

Source: own research.

According to data from the first store, the software has been downloaded more than 5,000 times ${ }^{2}$ since its release in June 2019. The evaluation involved 26 users and the rating was 3.7/5.0. AppStore does not provide information on the number of application downloads and the small number of reviews (4) indicates that it is probably lower than for Google Play. The owners of devices with iOS rated the application as 3.8/5.0. The application received a total of 30 ratings with an average of 3.71 and the most frequently cited advantages of the software were:

- interesting information available,

- frequent content updates,

- transparent features,

- useful suggestions.

The catalogue of reported disadvantages included:

- lack of information on selected tourist attractions in Galicia,

- technical problems with the display of some of the content, for example maps on some devices,
- the application continues running in the background, it is not possible to disable it.

Importantly, negative feedback on the information available in the application are rare in relation to positive feedback. It is worth noting that over the 18 months since the VisitMalopolska software was made available, the application has been systematically developed. Observations made between September and December 2020 indicate that the database of tourist attractions has been extended at a dynamic pace, often in line with the expectations of users indicated in the comments. The biggest disadvantage of the software are the technical difficulties occurring during its use. Undoubtedly, these kinds of issue should be troubleshooted by the body responsible for the application (Office of the Marshal of the Małopolska Region).

On the basis of the assessment, it was concluded that the VisitMalopolska application supports the tourist in the realization of their travel plans of various types. The software presents ways of organizing tourist 
travel in the region in an attractive way and gives users an opportunity to get to know places of interest and combine them on their own or according to the suggestions of the application into a route. In addition, the user becomes familiar with cultural events taking place in the region. On the basis of the analysis, it was noted that due to the variety of available uses, the software can be considered as:

- a tourist guide to the region,

- a travel planner,

- a newsletter on events taking place in Małopolska,

- a gamification platform,

- a system that allows virtual travel in Małopolska.

It was concluded that the VisitMalopolska mobile application is an example of a comprehensive tool and it is able to meet the needs of a varied target audience. Importantly, the number of available functionalities and the number of described places, routes and events means it can be assumed that it is an innovative project among mobile applications supporting the development of tourism in a particular region in Poland.

\section{CONCLUSION}

The increase in the number of mobile device users is conducive to creating mobile tourist applications. The wireless communication provided by smartphones allows users to stay connected at almost any time and anywhere. As a result, mobile software can be a tool to constantly support the tourist while traveling and for this reason, more and more regions offer dedicated platforms for different kinds of tourists.

It is worth noting that comprehensive tools that combine many functionalities and provide access to a wide range of interesting content are particularly important. In order to decide to use a mobile application, the user must see the real benefits of using it, while at the same time, it is important that the software is intuitive and easy to use. The VisitMalopolska mobile application can be considered to meet these objectives. However, it may be an issue that the application has been downloaded so far only a few thousand times [the figure is estimated by the authors as between 6,000 and 7,000 downloads]. Against the background of tourism in the region, the size of which 2019 was estimated at 17.86 million (Borkowski et al., 2020), this is an insignificant number. It should also be noted that the application has only been available since June 2019 and, importantly, since March 2020, the restrictions related to the COVID-19 pandemic have been in force, which has greatly restricted tourism. Perhaps after these are lifted, interest in the software will increase, and so it should be developed in order to meet the requirements of potential users.
Moreover, it is worth noting that the content available in the application is updated almost daily and additionally supplemented on the basis of artificial intelligence. As a result, the program can be personalized on an ongoing basis. Such tools undoubtedly contribute to an increase in the perception of their usefulness, as well as to generating a belief in the attractiveness of a region's offer. In the future, this may translate into the effectiveness of initiated or planned promotional activities. On the basis of this discussion, it has been concluded that the VisitMałopolska application supports the tourist in making trips of various types, an example of a comprehensive tool that is capable of meeting the needs of different tourism segments.

The scope of the research as presented in the article is limited, connected mostly with use of the point method which is subject to a certain bias. However, the results are preliminary. This work will provide inspiration to conduct a broader analysis of the software based on quantitative and qualitative methods and the results of these studies will be summarized with observations made by the authors of the article. The activities proposed will involve a comprehensive analysis, including the formulation of constructive research objectives. It is also planned to make a comparison of VisitMalopolska with other applications for tourists available on the Polish market.

\section{ENDNOTES}

${ }^{1}$ The project was realized from the funds of the Regional Operational Programme of the Malopolska Region for 2014-2020, co-financed by the European Union.

${ }^{2}$ As of December 7, 2020.

\section{REFERENCES}

Borkowski, K., Grabiński T., Seweryn, R., Rotter, L., Mazanek, L., Grabińska, E. (2020). Ruch turystyczny w Małopolsce w 2019 roku. Kraków: Małopolska Organizacja Turystyczna.

Brennan, B. (2020). A convergence of mobile device application use and smart tourism: A comparison of Korean and Non-Korean smart tourists. The Journal of Internet Electronic Commerce Research, 20 (4), 145-160. https://doi.org/10.37272/ JIECR.2020.08.20.4.145

Brown, B., Chalmers, M. (2003). Tourism and mobile technology. Proceedings of the European Conference of Computer Supported Cooperative Work (ECSCW) (pp. 335-354). Cham: Springer. https://doi.org/10.1007/978-94-010-0068-0_18

Buhalis, D., Law, R. (2008). Progress in information technology and tourism management: 20 years on and 10 years after the Internet - the state of eTourism research. Tourism Management, 29 (4), 609-623. https://doi.org/10.1016/j.tourman.2008.01.005

Buonincontri, P., Micera, R. (2016). The experience co-creation in smart tourism destinations: A multiplecase analysis of 
European destinations. Information Technology and Tourism, 16 (3), 285-315. https://doi.org/10.1007/s40558-016-0060-5

Czajkowski, R., Nowakowski, W. (2015). iBeacons - mobilne usługi lokalizacyjne. Elektronika: Konstrukcje, Technologie, Zastosowania, 4, 47-50. http://dx.doi.org/10.15199/13.2015.4.9

Dąbrowski, G. (2019). Dostęp do Internetu w Polsce. W: Internet 2018/2019 (pp. 8-9). Retrieved from: https://www.iab.org.pl/ wp-content/uploads/2019/06/HBRP-raport-IAB-05-191-1.pdf (20.10.2020).

Dorcic, J., Komsic, J., Markovic, S. (2019). Mobile technologies and applications towards smart tourism - state of the art. Tourism Review, 74 (1), 82-103. https://doi.org/10.1108/ TR-07-2017-0121

Gadziński, J. (2018). Perspectives of the use of smartphones in travel behaviour studies: Findings from a literature review and a pilot study. Transportation Research. Part C: Emerging Technologies, 88, 74-86. https://doi.org/10.1016/j.trc.2018.01.011

Gierszewska, G., Romanowska, M. (2017). Analiza strategiczna przedsiębiorstwa. Warsaw: PWE.

Gmiterek, G. (2017). Wykorzystanie aplikacji mobilnych w muzeach - przegląd i analiza polskich projektów. E-mentor, 2 (69), 25-39. http://dx.doi.org/10.15219/em69.1296

Gretzel, U., Sigala, M., Xiang, Z., Koo, C. (2015). Smart tourism: Foundations and developments. Electronic Markets, 25 (3), 179-188. https://doi.org/10.1007/s12525-015-0196-8

Hamza, Z.A., Hammad, M. (2020). Testing approaches for web and mobile applications: An overview. International Journal of Computing and Digital Systems, 9 (4), 657-664. https://dx.doi. org/10.12785/ijcds/090413

Kachniewska, M. (2019). Tworzenie wartości dodanej na bazie kontekstowych aplikacji mobilnych (przypadek branży turystycznej). Kwartalnik Nauk o Przedsiębiorstwie, 3, 15-24. https:// doi.org/10.5604/01.3001.0013.4780

Kim, D., Kim, S. (2017). The role of mobile technology in tourism: Patents, articles, news, and mobile tour app reviews. Sustainability, 9 (11), 2082. https://doi.org/10.3390/su9112082

Komisja Europejska (2020). Biała ksiega w sprawie sztucznej inteligencji. Retrieved from: https://ec.europa.eu/info/sites/info/files/ commission-white-paper-artificial-intelligence-feb2020_pl.pdf $(20.10 .2020)$.

Kubiak, K. (2015). Ocena wybranych aplikacji mobilnych w opinii użytkowników. Zeszyty Naukowe Uniwersytetu Szczecińskiego, 875. Problemy Zarządzania, Finansów i Marketingu, 41 (2), 83-93. https://doi.org/10.18276/pzfm.2015.41/2-07

Law, R., Cheng Chu Chan, I., Wang, L. (2018). A comprehensive review of mobile technology use inhospitality and tourism. Journal of Hospitality \& Management, 27 (2), 626-648. https:// doi.org/10.1080/19368623.2018.1423251

Lee, H.E., Choi H.S. (2016). Improvements of the Korean tourism application, visit Korea, for foreigners-based on beacon functions. International Journal of Software Engineering and Its Applications, 10 (4), 103-116. https://doi.org/10.14257/IJSEIA.2016.10.4.11

Liang, S., Schuckert, M., Law, R., Masiero, L. (2017). The relevance of mobile tourism and information technology: An analysis of recent trends and future research directions. Journal of Travel and Tourism Marketing, 34 (6), 732-748. https://doi.org/10.108 0/10548408.2016.1218403

Manchak, I., Sanak-Kosmowska, K. (2018). Personalizacja usług jako trend rozwojowy na rynku usług turystycznych. Ekonomiczne Problemy Turystyki, 2 (42), 29-35. https://doi. org/10.18276/ept.2018.2.42-03

Manczak, I. (2014). Kształtowanie relacji partnerskich w turystyce. Przeglad Organizacji, 12, 21-26. https://doi.org/10.33141/ po.2014.12.04

Manczak, I., Sanak-Kosmowska, K., Bajak, M. (2019). Zastosowanie beaconów w komunikacji marketingowej muzeów z osobami niepełnosprawnymi. Zarzadzanie w Kulturze, 20 (4), 551-564. http://dx.doi.org/10.4467/20843976ZK.19.033.11712

Martin, F., Ertzberger, J. (2013). Here and now mobile learning: An experimental study on the use of mobile technology. Computers E Education, 68, 76-85. https://doi.org/10.1016/j. compedu.2013.04.021

Neuhofer, B., Buhalis, D., Ladkin, A. (2014). A typology of technology-enhanced tourism experiences. International Journal of Tourism Research, 16 (4), 340-350. https://doi.org/10.1002/ jtr.1958

Niemczyk, A. (2017). Aplikacje mobilne jako determinanta zachowań turystycznych (na przykładzie Krakowa). Prace Naukowe Uniwersytetu Ekonomicznego we Wroctawiu, 473, 370-380. https:// doi.org/10.15611/pn.2017.473.34

Nunes, M., Mayer, V. (2014). Mobile technology, games and nature areas: The tourist perspective. Tourism $\mathcal{E}$ Management Studies, 10 (1), 53-58.

Panasiuk, A. (2015). Nowoczesne technologie informacyjne $\mathrm{w}$ kształtowaniu innowacji na rynku turystycznym. Rozprawy Naukowe Akademii Wychowania Fizycznego we Wroctawiu, 49, 99-106.

Papińska-Kacperek, J. (2013). E-tourism services in Polish tourists' opinions. Problems of Management in the $21^{\text {st }}$ Century, (7) 1, 33-38.

Papińska-Kacperek, J. (2016). Miejskie aplikacje mobilne w turystyce kulturowej w Polsce. Turystyka Kulturowa, 2, 67-85. Retrieved from: http://turystykakulturowa.org/ojs/index.php/ tk/article/view/720/646 (20.10.2020).

Parys, T. (2016). Identyfikacja barier zastosowania technologii mobilnych z perspektywy użytkowników indywidualnych, Studia Ekonomiczne. Zeszyty Naukowe Uniwersytetu Ekonomicznego w Katowicach, 281, 142-154.

Pawłowska-Legwand, A. (2019). Wykorzystanie technologii informacyjno-komunikacyjnych $\mathrm{w}$ dostępie do informacji i usług turystycznych w świetle wyników badań przeprowadzonych wśród polskich turystów w województwie małopolskim. Turyzm/Tourism, 29 (2), 109-117. https://doi. org/10.18778/0867-5856.29.2.22

Peddie, J. (2017). Augmented reality: Where we will all live. Cham: Springer International Publishing. https://doi. org/10.1007/978-3-319-54502-8

Perez Pulido, A. (2016). Mobile app for tourist services using artificial intelligence methodologies. Conference on artificial intelligence with applications.

Piechota, N. (2014). Lokalizacyjna aplikacja mobilna jako narzędzie badań ruchu turystycznego miasta w długim okresie. Studia Oeconomica Posnaniensia, 2 (1), 121-135.

Przecławski, K. (1979). Socjologiczne problemy turystyki. Warszawa: Instytut Wydawniczy CRZZ.

Rasińska, R., Siwiński, W. (2015). Aplikacje mobilne jako innowacyjne źródła informacji turystycznej dla studentów. Rozprawy Naukowe Akademii Wychowania Fizycznego we Wrocławiu, 50, 74-80.

de Rosset, A., Zielonka, K. (2016). Aplikacje mobilne w muzeach, moda czy potrzeba? Muzealnictwo, 57, 236-244. https://doi. org/10.5604/04641086.1220430

Sharma, S., Kumar, P. (2020). Rest House Hybrid Mobile Application using Ionic Tool. International Research Journal of Engineering and Technology, 7 (4), 45-50.

da Silva, A.C, da Rocha, H.V. (2012). M-traveling: Mobile applications in tourism. International Journal for Infonomics, 5 (3/4), 618-630. https://doi.org/10.20533/iji.1742.4712.2012.0071

Spicy Mobile (2019). Turyści 2019. Retrieved from: https://spicymobile.pl/assets/doc/Turysci_2019.pdf (15.12.2020).

Stabryła, A. (2013). Metodyka osiągnięć przedsiębiorstwa. Zarzadzanie i Finanse, 4 (1), 317-332. 
Sznajder, A. (2014). Technologie mobilne w marketingu. Warsaw: Oficyna a Wolters Kluwer business.

Szyran-Resiak, A. (2016). Systematyka metod pokrewnych możliwych do zastosowania w ocenie jakości działalności marketingowej organizacji. Zeszyty Naukowe PWSZ w Płocku. Nauki Ekonomiczne, XXIII, 87-98.

Tan, G.W.-H., Lee, V.H., Lin, B., Ooi, K.-B. (2017). Mobile applications in tourism: The future of the tourism industry? Industrial Management \& Data Systems, 117 (3), 560-581. https://doi. org/10.1108/IMDS-12-2015-0490

Thompson, A., Strickland, A. (1997). Strategic management. concepts and cases. Boston: Irwin Professional Publishing.

VisitMalopolska (2020a). Projekt m_MSIT - mobilny Matopolski System Informacji Turystycznej. Retrieved from: https://visitmalopolska.pl/projekt-m_msit (20.10.2020).

VisitMalopolska (2020b). Zwiedzaj Małopolske z nowoczesnymi technologiami. Retrieved from: https://visitmalopolska. pl/-/zwiedzaj-malopolske-z-nowoczesnymi-technologiami(20.10.2020).
Xiang, Z., Magnini, V.P., Fesenmaier, D.R. (2015). Information technology and consumer behavior in travel and tourism: Insights from travel planning using the internet. Journal of Retailing and Consumer Services, 22, 244-249. https://doi. org/10.1016/j.jretconser.2014.08.005

Zawadzki, P. (2018). Aplikacje mobilne jako element systemu informacji turystycznej. Zeszyty Naukowe Uniwersytetu Ekonomicznego w Krakowie, 4 (976), 85-101. https://doi. org/10.15678/ZNUEK.2018.0976.0406

Zborowski, M., Łuczak, K. (2016). Propozycja doboru składowych struktury kryteriów oceny jakości aplikacji mobilnych na przykładzie wybranych bankowych aplikacji mobilnych w Polsce. Annales Univesitas Marie Curie-Skłodowska Lublin-Polonia. Sectio H: Oeconomia, 50 (2), 183-202. https:// doi.org/10.17951/h.2016.50.2.183

Ziernicka-Wojtaszek, A., Zawora, T. (2011). Wybrane metody oceny atrakcyjności agroturystycznej obszarów wiejskich. Infrastruktura i Ekologia Terenów Wiejskich, 2, 235-245. 